\title{
Spontaneous pneuomopericardium: an unusual complication of abdominal carcinoma
}

\author{
Matias Trbušić*, \\ Zdravko Babić, \\ Marin Pavlov, \\ Krešimir Kordić \\ University Hospital Centre \\ "Sestre milosrdnice", \\ Zagreb, Croatia
}

\begin{abstract}
KEYWORDS: pneumopericardium, pericardiocentesis, cardiac tamponade. CITATION: Cardiol Croat. 2016;11(3-4):140. | DOI: http://dx.doi.org/10.15836/ccar2016.140
\end{abstract}

*ADDRESS FOR CORRESPONDENCE: Matias Trbušić, Klinički bolnički centar Sestre milosrdnice, Vinogradska 29, HR-10000 Zagreb, Croatia. / Phone: +385-99-378-7064 / E-mail: matias.trbusic@gmail.com

ORCID: Matias Trbušić, http://orcid.org/0000-0001-9428-454X · Zdravko Babić, http://orcid.org/0000-0002-7060-8375 Marin Pavlov, http://orcid.org/0000-0003-3962-2774 • Krešimir Kordić, http://orcid.org/0000-0002-9707-6946

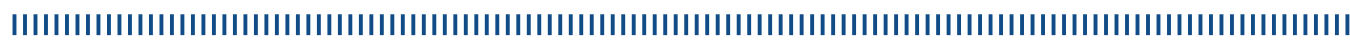

Pneumopericardium is a rare condition defined as a collection of air in the pericardial cavity. It is usually caused by blunt or penetrating chest injuries, iatrogenic causes (bone marrow puncture, thoracic surgery, pericardiocentesis, endoscopic procedures), and infectious pericarditis with gas-producing organisms. ${ }^{1,2}$

We present a case of 82-year-old female patient with spontaneous pneumopericardium caused by malignant ulcer that created fistula between the pericardium and an adjacent air-containing organ (colon). She was admitted in critical condition with chest pain, severe respiratory distress, hypotension, distended neck veins and tachyarrhythmia. High blood leukocyte and C-reactive protein levels and combined respiratory and metabolic acidosis were present. On auscultation, very unusual high frequency metallic sound was heard. 12-lead electrocardiogram showed atrial fibrillation and diffuse microvoltage. Chest X ray and CT showed normal sized heart completely surrounded by air (halo sign) below the aortic arch, and also large left pleural effusion. CT also revealed neoplastic process of the transverse colon infiltrating stomach and diaphragm. An echocardiogram demonstrated intrapericardial spontaneous contrast echoes followed by extreme difficulty to view the heart. Even so, significant respiratory variations in transvalvular blood flow velocities and dilated inferior vena were noticed indicating the tension pneumopericardium caused probably by a valve mechanism, resulting in cardiac tamponade. ${ }^{3}$ Under fluoroscopy control emergent pericardiocentesis was performed with needle extraction of $160 \mathrm{~mL}$ of very unpleasant smelled air. Mechanical ventilation was also started together with antibiotic therapy, volume replacement and pleural drainage. The patient was stabilized and next day transferred to another clinic in satisfied condition were the complex abdominal surgery was performed.

In conclusion, spontaneous pneumopericardium is a rare life threatening condition that can be caused by infiltrating malignant process. It can be rapidly recognized by physical examination and standard diagnostic tests. If valve mechanism is present it can result in tamponade requiring immediate pericardiocentesis as a life saving procedure.
RECEIVED:

January 16, 2016

ACCEPTED:

February 20, 2016

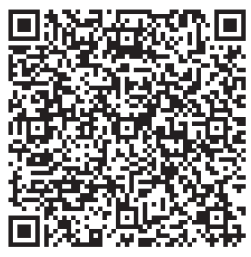

$\square$ Cardiologia Croatica 2016;11(3-4):140.
VII. nacionalni sastanak o kardiovaskularnim intervencijama s međunarodnim sudjelovanjem VI. sastanak intervencijskih kardioloških medicinskih sestara i tehničara

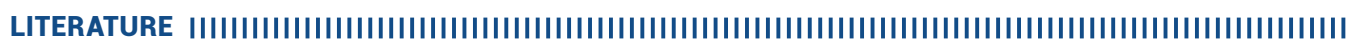

1. Westermann GW, Suwelack B. Spontaneous pneumopericardium due to exertion. South Med J. 2003;96(1):50-2. DOI: http://dx.doi.org/10.1097/01.SMJ.0000047762.92538.EC

2. Katzir D, Klinovsky E, Kent V, Shucri A, Gilboa Y. Spontaneous pneumopericardium: case report and review of the literature. Cardiology 1989;76(4):305-8. PubMed: http://www.ncbi.nlm.nih.gov/pubmed/2680082

3. Cummings RG, Wesly RL, Adams DH, Lowe JE. Pneumopericardium resulting in cardiac tamponade. Ann Thorac Surg. 1984;37(6):511-8. DOI: http://dx.doi.org/10.1016/\$0003-4975(10)61146-0 